\title{
Linkage analysis of five fibrillar collagen loci in a large French Marfan syndrome family
}

\author{
C Boileau, G Jondeau, C Bonaiti, M Coulon, G Delorme, O Dubourg, J-P Bourdarias, C Junien
}

\begin{abstract}
Marfan syndrome consists of a group of dominantly inherited disorders of connective tissue with wide clinical variability. Using the candidate gene approach, we have attempted to map the gene defect in a large French Marfan syndrome family with no ocular manifestations. We performed linkage studies with polymorphic probes for five structural procollagen genes. The data obtained exclude linkage of Marfan syndrome to the two major fibrillar collagen (COL1A1, COL1A2, and COL2A1) genes. These results confirm previously published data obtained from smaller pedigrees. A small positive lod score $(Z=0.99, \theta=0.00)$ was obtained for the COL3A1-COL5A2 gene cluster located on chromosome 2 .
\end{abstract}

Marfan syndrome (MS), an autosomal dominant disease, is associated with ocular, cardiovascular, and skeletal abnormalities. Variability of clinical expression is a hallmark of the disorder. The incidence of MS has been estimated at 1/25 000 and about one quarter of the cases are thought to result from new mutations. ${ }^{1}$

Although MS was the 'founding member' of inherited matrix disorders, ${ }^{2}$ it has remained an unmapped disease. Numerous biochemical reports have implied that it could be an inborn error of protein metabolism, particularly in collagen or elastin.

Laboratoire de Biochimie et de Génétique Moléculaire, Hôpital Ambroise Paré, 92000 Boulogne, France. C Boileau, C Junien

INSERM U73, Château de Longchamp, Bois de Boulogne, 75016 Paris, France.

C Boileau, M Coulon, C Junien

Service de Cardiologie, Hôpital Ambroise Paré, 92000 Boulogne, France.

G Jondeau, G Delorme, O Dubourg, J-P Bourdarias

INSERM U155, Château de Longchamp, 75016 Paris, France.

C Bonaiti

Correspondence to Dr Junien, Paris.

Received for publication 11 August 1989.

Revised version accepted for publication 8 November 1989.
However, the underlying pathogenesis of MS remains unknown. One approach to identifying the mutant . locus is by the 'candidate gene approach': genetic $\overrightarrow{\vec{\omega}}$ linkage studies are performed in multiplex families $\stackrel{\circ}{\circ}$ with candidate loci encoding components of the extracellular matrix. Several groups have already published exclusion data obtained with the major candidates, the fibrillar procollagen genes (for review $N$ see Francomano $e t a l^{3}$ ). However, clinical variability $\infty$ between MS families is the rule and could result from defects in different connective tissue components. Therefore, it is important to confirm, in each pedigree, $T$ previously reported exclusions, for there always 은 remains the possibility that the mutant gene may be one of the genes already excluded. Using an excep- $\rightleftharpoons$ tionally large French kindred with MS, we have $\overrightarrow{0}$ attempted to map the gene defect using the sange approach.

\section{Material and methods}

PATIENTS

Forty-nine members of a large French pedigree (figure), comprising to date 173 subjects with at least $\overrightarrow{\overrightarrow{0}}$ four generations affected, were tested: three from 3 generation II $(2,8,10), 20$ from generation III $(2,3$, $4,5,10,11,12,13,16,20,29,33,35,36,37,40,41$, $43,44,52)$, and 26 from generation IV $(7,8,9,10,13$, $14,17,18,24,26,29,30,32,35,42,44,46,49,51$, $52,53,54,55,57,58,59)$. The family was ascertained by one of us (J-PB) through the Department of Cardiology, Hôpital Ambroise Paré. This family had been under medical surveillance since 1977 after the death of a second sib from ruptured dissecting aneurysm of the ascending aorta. Histological studies $\supset$ in two patients showed that elastic fibres of the media were separated and disrupted by collagen fibrils and N mucoid material. Of the 37 subjects (mean age 28.3 years) in two generations who underwent physical 0 examination, echocardiography, and slit lamp $\mathbb{N}^{-}$ examination, 19 were considered to be genetically? affected since they had manifestations in two out of o the three systems involved, namely skeletal and cardiovascular. ${ }^{4}$ At least one skeletal anomaly was $\stackrel{\mathcal{?}}{+}$ observed in $89 \%$ of them: arachnodactyly $(38.9 \%)$, 0 narrow arched palate $(33.3 \%)$, pectus excavatum $(16 \cdot 7 \%)$, and scoliosis $(16 \cdot 7 \%)$. Increased lower-upper 


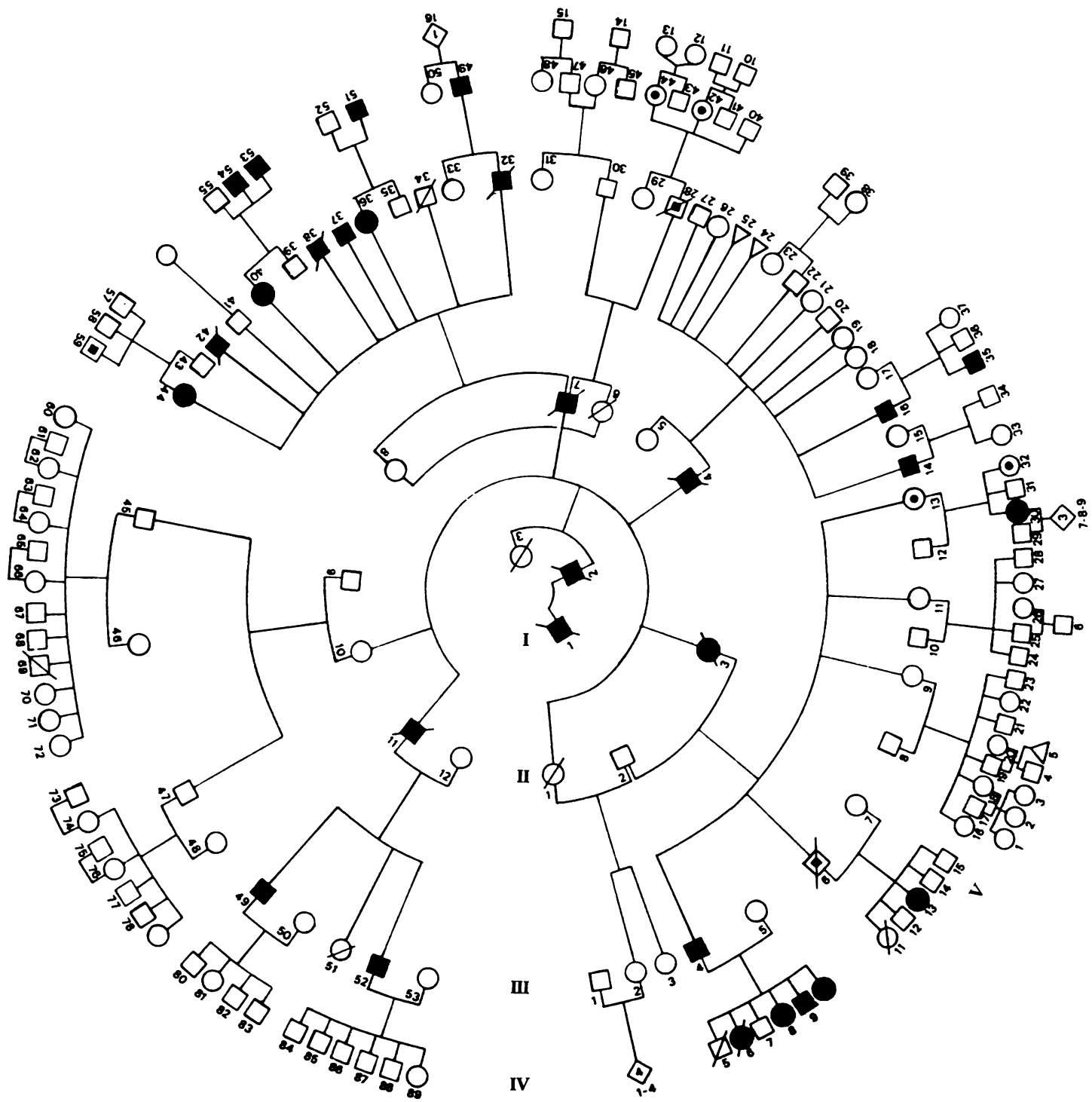

Family pedigree. Filled symbols indicate affected subjects; partially filled symbols indicate either an obligate carrier or persons with insufficient evidence for diagnosis. On linkage analysis only the obligate carrier III 13 was considered as affected.

body segment ratio, tall stature, and increased arm span were observed in all affected subjects. Two dimensional echocardiography and Doppler studies showed mitral valve prolapse $(66.4 \%)$ associated with holosystolic mitral regurgitation $(26 \cdot 3 \%),{ }^{5}$ tricuspid valve prolapse $(26.3 \%)$, and dilatation of the ascending aorta $(58 \%){ }^{6}$ None of the affected subjects examined had ectopia lentis.
RFLP ANALYSIS

DNA was prepared from peripheral blood leucocytes or Epstein-Barr virus transformed lymphoblastoid cell lines as previously described. ${ }^{7}$ Restriction enzyme digests were performed according to manufacturers' instructions and fragments were resolved by $0.8 \%$ agarose gel electrophoresis. DNA was transferred to Hybond-N membranes (Amersham) that were (pre) 
Table 1 Probes and RFLPs.

\begin{tabular}{|c|c|c|c|c|c|c|}
\hline Gene & $\begin{array}{c}\text { Chromosomal } \\
\text { localisation }\end{array}$ & Probe & $\begin{array}{l}\text { Restriction } \\
\text { enzyme }\end{array}$ & $\begin{array}{l}\text { Allelic } \\
\text { fragments } \\
(\mathrm{kb})\end{array}$ & $\begin{array}{c}\text { Allele } \\
\text { frequency }\end{array}$ & References \\
\hline COLlA1 & $17 \mathrm{q} 21.3 \rightarrow \mathrm{q} 22$ & $\mathrm{XHO}$ & Rsal & $\begin{array}{l}3.6 \\
2 \cdot 6\end{array}$ & $\begin{array}{l}0.14 \\
0.86\end{array}$ & 9 \\
\hline COL1A2 & $7 \mathrm{q} 21.3 \rightarrow \mathrm{q} 22.1$ & Hf32 & $R s a \mathrm{I}$ & $\begin{array}{l}2 \cdot 9 \\
2 \cdot 1+0 \cdot 8\end{array}$ & $\begin{array}{l}0.11 \\
0.89\end{array}$ & 10 \\
\hline COL2Al & $12 \mathrm{q} 14.3$ & pgHColIIA & HindIII & $\begin{array}{r}14 \cdot 0 \\
7 \cdot 0\end{array}$ & $\begin{array}{l}0.65 \\
0.35\end{array}$ & 11 \\
\hline \multirow[t]{2}{*}{ COL3Al } & $2 \mathrm{q} 14 \longrightarrow \mathrm{q} 32$ & pPB1 & $E c o$ RI & $\begin{array}{l}2 \cdot 1 \\
1 \cdot 7\end{array}$ & $\begin{array}{l}0.39 \\
0.61\end{array}$ & $\begin{array}{l}\text { R Dalgleish, } \\
\text { personal } \\
\text { communicatio }\end{array}$ \\
\hline & & pPB1 & AvaII & $\begin{array}{l}6 \cdot 2 \\
4 \cdot 5\end{array}$ & $\begin{array}{l}0.74 \\
0.26\end{array}$ & 12 \\
\hline COL5A2 & $2 \mathrm{q} 14 \longrightarrow \mathrm{q} 32$ & $\mathrm{NH} 2$ & $M s p \mathrm{I}$ & $\begin{array}{r}13 \cdot 0 \\
9 \cdot 0\end{array}$ & $\begin{array}{l}0.15 \\
0.85\end{array}$ & 13 \\
\hline
\end{tabular}

Table 2 Detailed results of pairwise linkage analysis of MS and collagen gene markers.

\begin{tabular}{|c|c|c|c|c|c|c|c|c|c|c|c|c|}
\hline \multirow[b]{2}{*}{ Locus 1} & \multicolumn{2}{|r|}{ Locus 2} & \multicolumn{10}{|c|}{ Lod score at recombination fractions of: } \\
\hline & Gene & Probe/enzyme & 0.000 & 0.001 & 0.01 & 0.05 & $0 \cdot 10$ & $0 \cdot 15$ & $0 \cdot 20$ & 0.25 & $0 \cdot 30$ & $0 \cdot 40$ \\
\hline $\begin{array}{l}\text { MS } \\
\text { MS } \\
\text { MS } \\
\text { MS } \\
\text { MS }\end{array}$ & $\begin{array}{l}\text { COLlA1 } \\
\text { COL1A2 } \\
\text { COL2A1 } \\
\text { COL3A1 } \\
\text { COL3A1 } \\
\text { COL5A2 }\end{array}$ & $\begin{array}{l}\text { XHO/RsaI } \\
\text { Hf32/RsaI } \\
\text { pgHColIIA/HindIII } \\
\text { pPB1/EcoRI } \\
\text { pPB } 1 / A v a I I \\
\text { NH2/MspI }\end{array}$ & $\begin{array}{r}-4.666 \\
-5.626 \\
-4.971 \\
-0.012 \\
-0.005 \\
0.992\end{array}$ & $\begin{array}{r}-2 \cdot 115 \\
-4 \cdot 102 \\
-4.972 \\
-0.012 \\
-0.005 \\
0.991\end{array}$ & $\begin{array}{r}-1 \cdot 130 \\
-2.242 \\
-4.692 \\
-0.012 \\
-0.005 \\
0.981\end{array}$ & $\begin{array}{r}-0.489 \\
-0.751 \\
-2.693 \\
-0.009 \\
-0.003 \\
0.925\end{array}$ & $\begin{array}{r}-0.258 \\
-0.173 \\
-1.659 \\
-0.007 \\
-0.002 \\
0.836\end{array}$ & $\begin{array}{r}-0.148 \\
0.080 \\
-1.075 \\
-0.005 \\
-0.001 \\
0.731\end{array}$ & $\begin{array}{r}-0.087 \\
0.192 \\
-0.693 \\
-0.004 \\
-0.001 \\
0.614\end{array}$ & $\begin{array}{r}-0.052 \\
0.226 \\
-0.431 \\
-0.003 \\
-0.000 \\
0.489\end{array}$ & $\begin{array}{r}-0.032 \\
0.215 \\
-0.250 \\
-0.002 \\
-0.000 \\
0.360\end{array}$ & $\begin{array}{r}-0.014 \\
0.123 \\
-0.052 \\
-0.000 \\
-0.000 \\
0 \cdot 128\end{array}$ \\
\hline
\end{tabular}

hybridised, washed, and exposed as previously reported. ${ }^{7}$ Probes were labelled with ${ }^{32} \mathrm{P}$ dCTP by random priming ${ }^{8}$ to high specific activity. Detailed information on the molecular probes and RFLPs tested is given in table $1 .^{9-13}$

\section{LINKAGE ANALYSIS}

Linkage analysis was performed with the program LINKAGE. ${ }^{14} \mathrm{~A}$ frequency for the disease allele of 0.00002 and a penetrance of $90 \%$ were used.

\section{Results}

Forty-nine members of the pedigree, including 18 affected subjects, were first screened with probes from four procollagen candidate genes: COL1Al, COL1A2, COL2A1, and COL3A1. Detailed results of pairwise linkage analyses between $M S$ and each of the RFLPs are shown in table 2.

The family was informative for the COL1Al, COL1A2, and COL2A1 markers. Strong evidence against linkage was found for these genes with respective maximum lod scores of $-4.66,-5.62$, and -4.97 at $\theta=0.00$. For COL3A1, the two RFLPs tested were not informative. However, since the COL3A1 and the COL5A2 genes both map to $2 \mathrm{q} 14 \rightarrow \mathrm{q} 32^{15}{ }^{16}$ and are tightly linked, ${ }^{17}$ probe NH2, which detects an MspI RFLP in COL5A2, was used It generated a small positive lod score $(Z=0.99$, $\theta=0 \cdot 00$ ).

\section{Discussion}

Although a defect in one of the major collagen genes has long been thought to be implicated in the pathogenesis of MS, our results exclude linkage between the disease and either the type I or type II procollagen genes. Other authors have also published exclusion data between the disease and these loci. $^{3}{ }^{18-20}$ In these studies, one or a few much smaller and clinically heterogeneous pedigrees were reported. Because of the great variability observed between MS families, which could be the result of heterogeneous underlying defects, our results should be compared only with data originating from phenotypically similar cases. (1) Francomano et $\mathrm{al}^{3}$ reported five out of 12 pedigrees without ectopia lentis. Among them, exclusion $(\mathrm{Z}=-\infty, \theta=0.00)$ of the three loci tested (COL1A2, COL2A1, and COL3A1) was obtained in only one family. (2) Of the families studied by Ogilvie et al, ${ }^{20}$ only two did not have ocular involvement. Neither of the type I procollagen genes could be clearly excluded in the two families. No data concerning linkage between $M S$ and $C O L 2 A 1$ or $C O L 3 A 2$ were reported. Our results, obtained in a 
single large pedigree, confirm the exclusion data for collagens type I and II.

Linkage between MS and the COL3A1-COL5A2 gene cluster was not fully investigated in either of the previous studies. The small positive result obtained in our study cannot be investigated further by the candidate gene approach since no other RFLPs than the ones reported here have been described for the cluster. Interestingly, the long arm of chromosome 2, along with the COL $3 \mathrm{~A} 1$ and COL5A2 genes, harbours other candidate genes such as elastin $(2 \mathrm{q} 31 \rightarrow \mathrm{qter})$, COL6A3 (2q37), and fibronectin (2q34 $\rightarrow$ q36). Further linkage studies between MS and the three candidate loci, as well as anonymous polymorphic DNA markers closely linked to the cluster in $2 \mathrm{q} 14 \rightarrow \mathrm{q} 32$, should elucidate the ambiguous results presented here.

The collagen candidate gene approach has now been used by many groups to map the gene defect in connective tissue disorders. It has only been successful in several types of osteogenesis imperfecta ${ }^{921}$ and Ehlers-Danlos syndrome. ${ }^{22}$ In the case of MS no conclusive data have been reported using this approach. Though there are other candidate genes among the components of the extracellular matrix, it is likely that the best approach to the Marfan locus will now be achieved by linkage analysis with evenly dispersed anonymous DNA markers.

We are indebted to $\mathrm{R}$ Dalgleish and $\mathrm{C}$ Strom for providing probes $\mathrm{pPB} 1$ and pgHCOLIIA respectively, and to Drs Abgrall, Barbagelatta, and Lancelin, and Professor Delahaye for examining members of the family. We thank $M$ Olivier for preparation of the manuscript. This work was supported by grants from Fédération de Cardiologie, INSERM, Faculté de Médecine Paris-Ouest, and Conseil Scientifique de la Ville de Paris.

1 McKusick VA. The cardiovascular aspects of Marfan's syndrome: a heritable disorder of connective tissue. Circulation 1955;11: $321-42$.

2 McKusick VA. Mendelian inheritance in man. 8th ed. Baltimore: Johns Hopkins University Press, 1988.

3 Francomano C, Streeten E, Meyers D, Pyeritz R. Marfan syndrome: exclusion of genetic linkage to three major collagen genes. Am $\mathcal{F}$ Med Genet 1988;29:457-62.

4 Pyeritz AE, McKusick VA. The Marfan syndrome: diagnosis and management. N Engl f Med 1979;300:772-7.

5 Labowitz A, Pearson A, McCluskey M, Williams G. Clinical significance of the echocardiographic degree of mitral valve prolapse. Am Heart 7 1988;115:842-8.

6 Weyman AE. Normal cross-sectional echocardiographic measurements in adults. In: Cross sectional echocardiography. Philadelphia: Lea and Febiger, 1988:497-508.

7 Henry I, Uzan G, Nicolas H, et al. The genes coding for Aa-, $\mathrm{B} \beta$-, and $\gamma$-chains of fibrinogen map to 4q. Am $\mathcal{F}$ Hum Genet 1984;36:760-8.

8 Feinberg A, Vogelstein B. A technique for radiolabelling DNA restriction endonuclease fragments to high specific activity. Anal Biochem 1983;132:6-13.

9 Sykes B, Wordsworth P, Ogilvie D, Anderson J, Jones N. Osteogenesis imperfecta is linked to both type I collagen structural genes. Lancet 1986;ii:69-72.

10 Grobler-Rabie A, Wallis G, Brebner D, Beighton P, Bester A Mathew C. Detection of a high frequency Rsal polymorphism in the human pro-alpha-2 (I) collagen gene which is linked to an autosomal dominant form of osteogenesis imperfecta. $E M B O \mathcal{F}$ 1985;7:1745-8

11 Eng C, Strom C. Analysis of three restriction fragment length polymorphisms in the human type II procollagen gene. Am $\mathcal{f}$ Hum Genet 1985;37:719-32.

12 Dalgleish R, Woodhouse M, Reeders S. An RFLP associated with the human type III collagen gene (COL $3 A 1)$. Nucleic Acids Res 1985;13:4609.

13 Schwartz R, Lidell A, Ramirez F, Tsipouras P. An RFLP in the gene for the human pro-alpha 2 chain of type $\mathrm{V}$ collagen (COL5A2). Nucleic Acids Res 1988;16:5225.

14 Lathrop G, Lalouel JM, Julier C, Ott J. Strategies for multilocus linkage analysis in humans. Proc Natl Acad Sci USA 1984;81: 3443-6.

15 Emanuel BS, Cannizzari LA, Seyers JM, Meyers JC. Human $\alpha 1$ (III) and $\alpha 2(V)$ procollagen genes are located on the long arm of chromosome 2. Proc Natl Acad Sci USA 1985;82:3385-9.

16 Huerre-Jeanpierre C, Henry I, Bernard M, et al. The proa2(V) collagen gene (COL5A2) maps to $2 \mathrm{q} 14 \rightarrow 2 \mathrm{q} 32$, syntenic to the proal(III) collagen locus (COL3Al). Hum Genet 1986;73:64-7.

17 Tsipouras P, Schwartz R, Lidell A, Scott Salkeld C, Weil D, Ramirez F. Genetic distance of two fibrillar collagen loci, COL $3 A 1$ and COLSA2, located on the long arm of human chromosome 2. Genomics 1988;3:275-7.

18 Tsipouras P, Borresen AL, Bamforth S, Harper P, Berg $\mathrm{K}$. Marfan syndrome: exclusion of genetic linkage to the COL1A2 gene. Clin Genet 1986;30:428-32.

19 Dalgleish R, Hawkins J, Keston M. Exclusion of the $\alpha 2(I)$ and $\alpha \mathrm{I}(\mathrm{III})$ collagen genes as the mutant loci in a Marfan syndrome family. $\mathcal{F}$ Med Genet 1987;24:148-51.

20 Ogilvie D, Wordsworth B, Priestley L, et al. Segregation of all four major fibrillar collagen genes in the Marfan syndrome. Am f Hum Genet 1987;41:1071-82.

21 Byers $\mathrm{P}$, Tsipouras P, Bonadio J, Starman B, Schwartz R. Perinatal lethal osteogenesis imperfecta (OI type II): a biochemically heterogeneous disorder usually due to new mutations in the genes for type I collagen. Am $\mathcal{F}$ Hum Genet 1988;42: 237-48.

22 Superti-Furga A, Steinmann B, Ramirez F, Byers P. Molecular defects of type III procollagen in Ehlers-Danlos syndrome type IV. Hum Genet 1989;82:104-9. 